\title{
Agreia bicolorata gen. nov., sp. nov., to accommodate actinobacteria isolated from narrow reed grass infected by the nematode Heteroanguina graminophila
}

\author{
${ }^{1}$ All-Russian Collection of \\ Microorganisms (VKM), \\ G. K. Skryabin Institute of \\ Biochemistry and \\ Physiology of \\ Microorganisms, Russian \\ Academy of Sciences, \\ Pushchino, Moscow \\ Region 142290, Russia \\ 2,3 Department of Soil \\ Science $^{2}$ and School of \\ Biology ${ }^{3}$, Lomonosov \\ Moscow State University, \\ Moscow 119899, Russia \\ 4 Institute of Parasitology, \\ Russian Academy of \\ Sciences, Leninskii \\ prospect 33, Moscow \\ 117071, Russia \\ 5 Center for Microbial \\ Ecology, Michigan State \\ University, East Lansing, \\ MI 48824-1325, USA
}

\author{
Lyudmila I. Evtushenko, ${ }^{1}$ Lubov V. Dorofeeva, ${ }^{1}$ Tatyana \\ G. Dobrovolskaya, ${ }^{2}$ Galina M. Streshinskaya, ${ }^{3}$ Sergey A. Subbotin ${ }^{4}$ \\ and James M. Tiedje ${ }^{5}$
}

Author for correspondence: Lyudmila I. Evtushenko. Tel: +7 095 9257448. Fax: + 70959563370. e-mail: evtushenko@ibpm.serpukhov.su

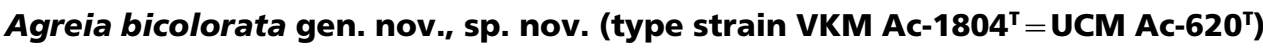
is proposed to accommodate aerobic, oxidase- and catalase-positive, weakly motile, coryneform actinobacteria isolated from leaf galls induced by the plant-parasitic nematode Heteroanguina graminophila in narrow reed grass, Calamagrostis neglecta. Bacteria assigned to Agreia bicolorata gen. nov., sp. nov. form a distinct lineage within the phylogenetic branch of the family Microbacteriaceae and possess the following chemotaxonomic characteristics: B-type peptidoglycan containing 2,4-diaminobutyric acid, ornithine, alanine, glycine, glutamate and hydroxyglutamate; cell wall sugars rhamnose, fucose and mannose; MK-10 as major menaquinone; phosphatidylglycerol and diphosphatidylglycerol as principal phospholipids; and 12-methyltetradecanoic acid (anteiso-15:0), 14-methyl-pentadecanoic acid (iso-16:0) and 14-methyl-hexadecanoic acid (anteiso-17:0) as predominant fatty acids. The DNA G+C content of Agreia bicolorata is about $67.0 \mathrm{~mol} \%$.
\end{abstract}

Keywords: Actinomycetales, Agreia bicolorata gen. nov., sp. nov., plant-parasitic nematode, Heteroanguina graminophila

\section{INTRODUCTION}

A number of coryneform bacteria have been reported to be involved in an intimate relationship with plantparasitic nematodes of the genus Anguina (Gupta \& Swarup, 1972; Gummins et al., 1975; Price et al., 1979; Bird, 1981; Riley, 1987; Riley et al., 1988; Riley \& McKay, 1990; Riley \& Ophel, 1992; McKay \& Ophel, 1993). Bacteria attached to the surface of the infective nematode are carried into the growing points of host plants and can multiply there causing certain plant diseases (Gummins et al., 1975; Vidaver, 1982; Bradbury, 1986; Collins \& Bradbury, 1991). They may also inhabit many galls induced by nematodes in seeds, leaves, stems and roots (Bird, 1981; Evtushenko et al., 1994). These bacterial associates of nematodes may facilitate development of nematode larvae within the

Abbreviation: DAB, 2,4-diaminobutyric acid.

The GenBank accession number for the 16S rRNA sequence of strain VKM Ac- $1804^{\top}$ is AF159363. galls and release of nematodes from the galls, destroying the gall envelope by fermentative activities (Bird, 1981, 1985). The unambiguously identified coryneform bacteria of such Anguina-bacterial communities have been assigned to different species of the genus Rathayibacter (Zgurskaya et al., 1993; Sasaki et al., 1998). Rathayibacter toxicus (formerly Clavibacter toxicus, also previously referred to as Corynebacterium sp., Corynebacterium rathayi, annual ryegrass toxicity bacteria or 'ARGT' bacteria) may produce neurotoxins of glycolipid character in the infected plants which are harmful for grazing animals (Vogel et al., 1982; Jago et al., 1983; Riley, 1987; McKay \& Ophel, 1993). The toxin responsible for annual ryegrass toxicity was shown to be produced when bacteria were infected with a bacteriophage (Ophel et al., 1993). Other microorganisms may also be involved in Anguina-bacteria disease complexes in the absence of the rathayibacterial type associates (Wen \& Viglierchio, 1992).

Very little is known about micro-organisms associated with gall-forming nematodes of other genera of the 
subfamily Anguininae (Krall, 1991; Subbotin \& Ivanova, 1991). Our electron microscopic study of galls induced by nematodes of the genera Heteroanguina, Mesoanguina and Subanguina in different grasses showed a significant accumulation of irregular Grampositive rods in the cavities, intracellular space and destroyed cells of the galls. Some coryneform bacteria isolated from these galls have been identified as members of the genera Curtobacterium, Microbacterium and Rhodococcus (Evtushenko et al., 1994), which are known to be widely spread in the phyllosphere of different plants as saprophytes or plant pathogens (Vidaver, 1982; Collins \& Bradbury, 1991). The bacteria found in root galls of annual meadow grass infected by the nematode Subanguina radicicola have been described as Leifsonia poae gen. nov., sp. nov. (Evtushenko et al., 2000). Results of a taxonomic study of coryneform bacteria isolated from leaf galls induced by the nematode Heteroanguina graminophila in narrow reed grass, Calamagrostis neglecta, are presented. Based on the data obtained, a new genus and species, Agreia bicolorata gen. nov., sp. nov., is proposed.

\section{METHODS}

Isolation and cultivation of bacteria. Narrow reed grass (Calamagrostis neglecta) samples infected by the gall-forming nematode Heteroanguina graminophila were collected in Moscow Region in June 1991 and stored dry in sterile Petri dishes at $8^{\circ} \mathrm{C}$ for 2 years. The galls were cut from the leaves with a sterile scalpel, treated with a detergent and washed with sterile water. They were then cut into pieces, added to $2 \mathrm{ml} 0.85 \% \mathrm{NaCl}(\mathrm{w} / \mathrm{v})$ solution and ground with a pestle. One drop of this suspension was plated onto nutrient agar ( $2 \mathrm{~g}$ peptone, $1 \mathrm{~g}$ glucose, $1 \mathrm{~g}$ yeast extract, $1 \mathrm{~g}$ casein peptone, $10 \mathrm{ml}$ glycerol, $5 \mathrm{~g}$ chalk, $100 \mathrm{ml}$ wort, $15 \mathrm{~g}$ agar, $900 \mathrm{ml}$ distilled water, $\mathrm{pH} 7 \cdot 2-7 \cdot 4)$ and incubated for 2 weeks at room temperature $\left(17-24^{\circ} \mathrm{C}\right)$. Bacteria from representative colonies were selected and regrown on the same medium or corynebacterial (CB) agar (pH 7·2-7·4), which contained $\left(1^{-1}\right): 5 \mathrm{~g}$ peptone, $5 \mathrm{~g}$ glucose, $3 \mathrm{~g}$ yeast extract, $10 \mathrm{~g}$ casein peptone, $5 \mathrm{~g} \mathrm{NaCl}$ and $15 \mathrm{~g}$ agar. Bacteria were stored at $8^{\circ} \mathrm{C}$ or freeze-dried. For the chemotaxonomic study, shake cultures were grown in liquid CB medium for $18 \mathrm{~h}$.

Morphology, physiology and cell chemistry. Morphology and life cycle were studied in cultures grown on CB agar by phase-contrast and electron microscopy as described previously (Evtushenko et al., 1994). Motility was studied by the hanging drop method. Physiological features were examined as described by Zgurskaya et al. (1993) and Evtushenko et al. (2000). For extraction of cell walls, crude cells were disrupted by sonication, separated from unbroken cells by fractional centrifugation, and purified using trypsin and $2 \%$ SDS as reported previously (Evtushenko et al., 2000). The presence of 2,4-diaminobutyric acid (DAB) and ornithine was detected by the TLC method (Bousfield et al., 1985). Quantitative determination of amino acids was performed with an LC $600 \mathrm{E}$ amino acid analyser (Biotronic) after acid hydrolysis $\left(6 \mathrm{M} \mathrm{HCl}, 105^{\circ} \mathrm{C}, 6 \mathrm{~h}\right)$ as described by Schleifer \& Kandler (1972). Sugars of whole cells and cell walls, the presence of mycolic acids, and the composition of

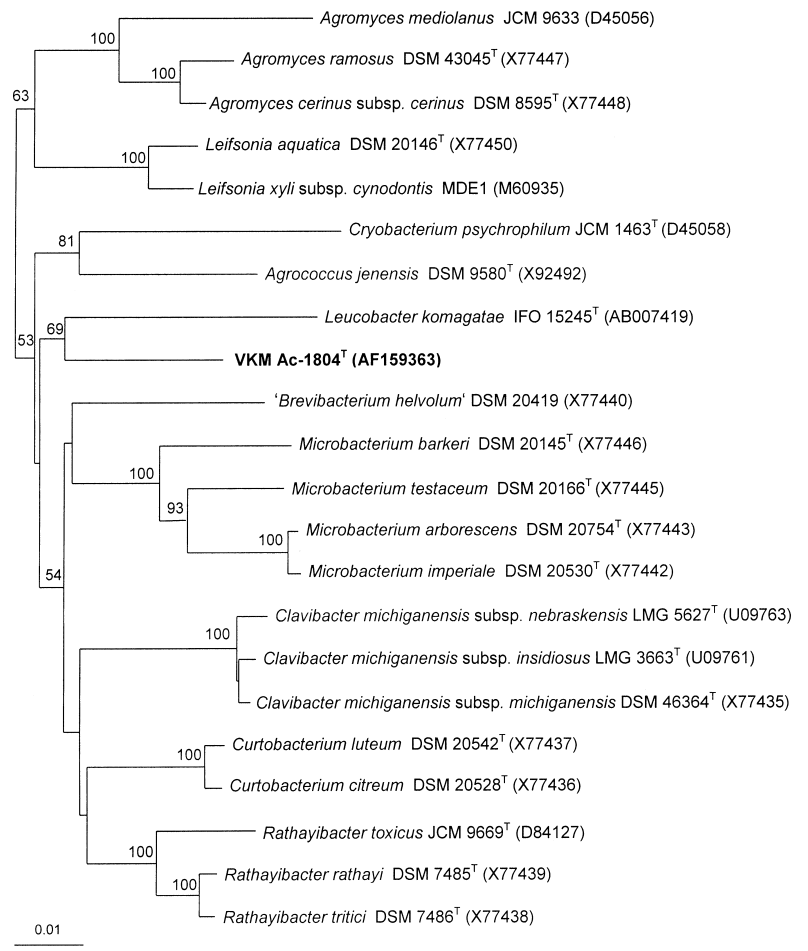

Fig. 1. Phylogenetic tree showing the position of strain VKM Ac- $1804^{\top}$ based on $16 \mathrm{~S}$ rDNA analysis. The sequence of Brevibacteriun linens DSM $20425^{\top}$ (X77451) served as the outgroup (not presented). Accession numbers of nucleotide sequences are given in parentheses. Numbers within the dendrogram indicate the percentages of occurrence of the branching order in 1000 bootstrapped trees. Bar, $1 \mathrm{nt}$ substitution per $100 \mathrm{nt}$.

menaquinones, fatty acids and phospholipids were studied as reported previously (Evtushenko et al., 1989, 2000).

DNA base composition, DNA-DNA reassociation and 165 rDNA sequence analyses. The methods used for extraction and purification of DNA and determination of the $\mathrm{G}+\mathrm{C}$ content by thermal denaturation have been described previously (Evtushenko et al., 1989). DNA-DNA hybridization was performed using the membrane filter method (Evtushenko et al., 2000). ${ }^{3} \mathrm{H}$-labelled DNAs from reference strains were obtained by in vitro nick-translation. The $16 \mathrm{~S}$ rRNA was amplified using the PCR method and prokaryotic 16S rDNA universal primers fD1 and rP1 (Weisburg et al., 1991) as described previously (Zhou et al., 1997). PCR products were detected by agarose gel electrophoresis, visualized by UV fluorescence after ethidium bromide staining, and then purified and concentrated using a Wizard PCR Preps DNA purification system (Promega). The 16S rDNA sequences were analysed directly using purified PCR products as the sequencing template. Sequencing reactions were performed with automated fluorescent Taq cycle sequencing using the ABI Catalyst 800 and a model ABI 373A automatic DNA sequencer (Applied Biosystems) according to the manufacturer's protocol. Nucleotide substitution rates were calculated as described by Kimura \& Ohta (1972) and the phylogenetic tree was constructed by the neighbour-joining method (Saitou \& Nei, 1987) with 
CLUSTAL W software (Thompson et al., 1994). Tree topologies were evaluated by bootstrap analysis of the sequence data with the same software. GenBank, DDBJ and EMBL accession numbers for reference $16 \mathrm{~S}$ rDNA sequences of the strains used in this analysis are given in Fig. 1. Brevibacterium linens DSM 20425 ${ }^{\mathrm{T}}$ (X77451) was used as the outgroup.

\section{RESULTS AND DISCUSSION}

\section{Isolation}

Numerous coryneform bacteria that formed colonies of different tints of yellow and orange developed from the ground gall suspensions plated on the isolation media. About 20-25\% semi-liquid bacterial colonies with brown-orange pigment were observed after 2 weeks incubation. Two representatives of the latter group, strains VKM Ac- $1804^{\mathrm{T}}$ and VKM Ac-1805, were characterized in detail.

\section{Morphology}

The colonies of both strains were round, glistening, opaque, butyrous, semi-fluid or fluid, at first deepyellow or yellow-orange and later becoming redorange or brown-orange on CB agar. Abundant polysaccharide capsules were usually formed on some agar media and liquid culture produced viscous slime. The young cells $(18-20 \mathrm{~h})$ were non-spore-forming, weakly motile, irregular rods $(0.4-0.5 \times 1.5-2.5 \mu \mathrm{m})$; primary branching was rarely observed. In older cultures, shorter irregular rods predominated as single cells; pairs or short chains with diphtheroid arrangements were also observed. However, a marked rodcoccus growth cycle did not occur. Electron microscopy revealed that the cell wall composition was typical of that of Gram-positive bacteria.

\section{Cell chemistry}

Cell walls contained DAB, ornithine, alanine, glycine and glutamate plus hydroxyglutamate in a molar ratio close to $1: 1: 2: 2: 2$, as well as muramic acid and glucosamine. Whole-cell sugars of all strains were similar and included predominantly glucose and rhamnose; fucose, mannose and ribose were minor components. Quantitative cell wall sugar analysis of strain VKM Ac- $1804^{\mathrm{T}}$ revealed rhamnose, fucose and mannose in a molar ratio of $7: 1: 0 \cdot 5$. Mycolic acids were not present. The major menaquinone was MK-10 and minor amounts of MK-9 were found in both strains; traces of MK-8 and MK-11 were also detected in VKM Ac-1804 ${ }^{\mathrm{T}}$. Phosphatidylglycerol and diphosphatidylglycerol were the principal phospholipids. The major fatty acids were anteiso- and iso-branched $(31 \cdot 3$ and $30 \cdot 2 \%$ anteiso-15:0, 26.6 and $27 \cdot 1 \%$ iso- $16: 0$, $39 \cdot 4$ and $41 \cdot 3 \%$ anteiso-17:0 in VKM Ac- $1804^{\mathrm{T}}$ and VKM Ac-1805, respectively). Other fatty acids (iso$15: 0,15: 0,16: 0$, iso-18:1,18:1 and iso-18:0) were present in small amounts $(0 \cdot 1-0 \cdot 8 \%)$.

\section{S rDNA gene sequence analysis}

An almost complete $16 \mathrm{~S}$ rRNA sequence (1468 nt) was determined in strain VKM Ac-1804 ${ }^{\mathrm{T}}$. Phylogenetic analysis indicated that this strain formed a distinct lineage within the phylogenetic cluster of the actinomycete genera that comprise the family Microbacteriaceae. It was linked to the type strain of Leucobacter komagatae, IFO $15245^{\mathrm{T}}$, with a $69 \%$ bootstrap replication value, showing $16 \mathrm{~S}$ rDNA gene sequence similarity of $94 \cdot 1 \%$ (Fig. 1).

\section{DNA base composition and DNA-DNA hybridization}

The DNA G + C contents of strains VKM Ac- $1804^{\mathrm{T}}$ and VKM Ac-1805 were $67 \cdot 0$ and $67 \cdot 2 \mathrm{~mol} \%$, respectively. The DNA-DNA similarity between these strains was $87 \cdot 4 \%$, clearly indicating that both strains belong to a common genomospecies.

\section{Physiology}

Strains VKM Ac-1804 ${ }^{\mathrm{T}}$ and VKM Ac-1805 were almost identical in more than 100 physiological characteristics studied, including sensitivity to different antibiotics. The strains were aerobic, catalase- and oxidase-positive, mesophilic, with a growth optimum at $24-26^{\circ} \mathrm{C}$. Voges-Proskauer test was positive and methyl red test was negative. $\mathrm{H}_{2} \mathrm{~S}$ was weakly produced. All strains used L-arabinose, D-glucose, Dgalactose, cellobiose, fructose, inositol (weak), inulin, lactose, maltose, mannose, mannitol, melibiose, raffinose, L-rhamnose, ribose, salicin, sorbitol, trehalose, turanose and D-xylose as a carbon source for growth in salt medium supplemented with $0 \cdot 1 \%(\mathrm{w} / \mathrm{v})$ yeast extract and $0 \cdot 1 \%(\mathrm{w} / \mathrm{v})$ casitone; none of the strains utilized adonitol, dextran, lyxose, meso-erythritol or sorbose as a carbon source. An alkaline reaction was observed with citrate, fumarate, gluconate (weak), $\alpha$ ketoglutarate and malate in both strains, but no reaction occurred with oxalate or tartrate. Utilization of succinate, acetate and propionate was negative only in strain VKM Ac-1804 ${ }^{\mathrm{T}}$. A few amino acids (DLleucine, DL-methionine and DL-proline) were weakly utilized as a source of nitrogen. Tween 40, Tween 80 and aesculin were hydrolysed, but starch, hypoxanthine and xanthine were not decomposed. Growth occurred in the presence of neomycin and streptomycin (both at $10 \mu \mathrm{g} \mathrm{ml}^{-1}$ ), but was inhibited by $6 \% \mathrm{NaCl}$ and the following antibiotics (at $10 \mu \mathrm{g} \mathrm{ml}^{-1}$ ): ampicillin, doxycycline, gentamicin, penicillin, rifampicin and tetracycline.

\section{Taxonomic affiliation of strains}

At the time of writing this report, the family Microbacteriaceae proposed by Park et al. (1993) contained ten genera which are characterized by B-type peptidoglycan (Table 1). Seven of them, Agromyces (Gledhill \& Casida, 1969), Clavibacter (Davis et al., 1984), Rathayibacter (Zgurskaya et al., 1993), Agrococcus (Groth et al., 1996), Leucobacter (Takeuchi et al., 
Table 1. Salient characteristics that differentiate Agreia gen. nov. from other genera of the family Microbacteriaceae

Data from Gledhill \& Casida (1969), Komagata \& Suzuki (1986), Davis et al. (1984), Zgurskaya et al. (1993), Groth et al. (1996), Takeuchi et al. (1996), Suzuki et al. (1997), Takeuchi \& Hatano (1998), Kämpfer et al. (2000) and Evtushenko et al. (2000). +, Positive; - negative.

\begin{tabular}{|c|c|c|c|c|c|c|c|}
\hline Genus & $\begin{array}{l}\text { Colony } \\
\text { colour* }\end{array}$ & Motility & $\begin{array}{c}\text { Diamino } \\
\operatorname{acid} \dagger\end{array}$ & Major MK* & $\begin{array}{c}\text { Fatty acid } \\
\text { type } \S\end{array}$ & $\mathbf{G}+\mathbf{C}(\mathbf{m o l} \%)$ & Growth at $28{ }^{\circ} \mathrm{C}$ \\
\hline Agreia gen. nov. & $\mathrm{Y}, \mathrm{O}, \mathrm{RO}, \mathrm{BO}$ & + & DAB, Orn & MK-10 & $\mathrm{S}, \mathrm{A}, \mathrm{I}$ & $67 \cdot 0$ & + \\
\hline Agrococcus & $\mathrm{O}, \mathrm{Y}$ & - & DAB & MK-11,12 & $\mathrm{S}, \mathrm{A}, \mathrm{I}$ & 74 & + \\
\hline Agromyces & $\mathrm{Y}, \mathrm{W}$ & - & DAB & MK-12 & $\mathrm{S}, \mathrm{A}, \mathrm{I}$ & $71-76$ & + \\
\hline Clavibacter & $\mathrm{Y}, \mathrm{O}, \mathrm{P}$ & - & DAB & MK-9 & S, A, I & $67-78$ & + \\
\hline Cryobacterium & $\mathrm{P}$ & - & DAB & MK-10 & $\mathrm{S}, \mathrm{A}, \mathrm{I},(12 \mathrm{H})$ & 65 & - \\
\hline Curtobacterium & $\mathrm{Y}, \mathrm{O}$ & $+1-$ & Orn & MK-9 & $\mathrm{S}, \mathrm{A}, \mathrm{I},(\mathrm{H})$ & $68-75$ & + \\
\hline Frigoribacterium & Y & + & Lys & MK-9 & $\mathrm{S}, \mathrm{A}, \mathrm{I}$ & $71 \cdot 7$ & - \\
\hline Leifsonia & Y & + & DAB & MK-11 & $\mathrm{S}, \mathrm{A}, \mathrm{I}$ & $66-73$ & + \\
\hline Leucobacter & W & - & DAB & MK-11 & $\mathrm{S}, \mathrm{A}, \mathrm{I}$ & $66 \cdot 2$ & + \\
\hline Microbacterium & $\mathrm{Y}, \mathrm{O}, \mathrm{W}$ & $+1-$ & Orn/Lys & MK-11, -12, -13, -14 & $\mathrm{S}, \mathrm{A}, \mathrm{I}$ & $65-72$ & + \\
\hline Rathayibacter & $\mathrm{Y}$ & - & DAB & MK-10 & $\mathrm{S}, \mathrm{A}, \mathrm{I}$ & $63-72$ & + \\
\hline
\end{tabular}

* BO, Brown-orange; O, orange; $\mathrm{P}$, pink; RO, red-orange; Y, yellow; W, white.

$\dagger$ DAB, 2,4-Diaminobutyric acid; Orn, ornithine; Lys, lysine.

† Designation of Collins \& Jones (1981).

$\S \mathrm{S}$, Straight-chain saturated; A, anteiso-methyl-branched; I, iso-methyl-branched; H, cyclohexyl fatty acid; 12H, 12-methyltetradecenoic acid; components given in parentheses are sometimes present.

1996), Cryobacterium (Suzuki et al., 1997) and Leifsonia (Evtushenko et al., 2000) possess the DAB-based peptidoglycans, whereas ornithine is the characteristic diamino acid of the genus Curtobacterium (Komagata \& Suzuki, 1986) and most Microbacterium spp. (Takeuchi \& Hatano, 1998). The morphology, amino acid composition, acyl type of peptidoglycan, menaquinone profile, phospholipid pattern, fatty acid type and growth temperature were proposed as salient characteristics to differentiate genera of the family at the phenetic level. In addition, D- or L-isomers of DAB (Sasaki et al., 1998), the polyamine pattern (Altenburger et al., 1997) and the presence of cell wall teichoic acids (Shashkov et al., 1993, 1995; Gnilozub et al., 1994) were indicative of some DAB-containing genera or species.

Isolates VKM Ac-1804 ${ }^{\mathrm{T}}$ and VKM Ac-1805 were notably distinguished among all the above genera of the family Microbacteriaceae at the phenetic level. The most striking features differentiating these strains from other genera of the family were the orange to redorange or brown-orange pigments of the colonies and the unusual composition of amino acids in their cell walls (see above). No bacteria having a combination of DAB and ornithine as diamino acids in their peptidoglycans have been described so far and the presence of both ornithine and glutamate plus hydroxyglutamate has been reported only in peptidoglycans of Microbacterium spp. (Takeuchi \& Hatano, 1998). Our strains also differed from most genera of the family Microbacteriaceae in their major menaquinone, which is an essential differentiating characteristic of genera con- taining DAB in their cell walls (Zgurskaya et al., 1993; Groth et al., 1996; Takeuchi et al., 1996; Suzuki et al., 1997; Sasaki et al., 1998). The above differences are in line with the significant phylogenetic separation of strain VKM Ac- $1804^{\mathrm{T}}$ within the Microbacteriaceae cluster (Fig. 1). Thus, on the basis of phenetic and phylogenetic distinctions of the gall bacteria from validly described genera of the family Microbacteriaceae, it is proposed that these organisms should be assigned to a novel genus, Agreia gen. nov. The high level of DNA-DNA similarity between VKM Ac- $1804^{\mathrm{T}}$ and VKM Ac-1805, along with the identity of these strains in their phenotypic characteristics, including fatty acid profiles and the numerous growth and physiological properties, indicate that both strains are members of one species, Agreia bicolorata gen. nov., sp. nov.

While this report was being reviewed, the description of another novel genus belonging to the family Microbacteriaceae, Subtercola gen. nov., was published (Männistö et al., 2000). Strains of this genus were isolated from boreal groundwater and differed markedly from our strains in some essential chemotaxonomic characteristics, e.g. the cell wall peptidoglycan was of the B-type and contained only DAB as diamino acid and lacked ornithine, the major menaquinones were MK-9 and MK-10 in almost equal proportions, and the fatty acid composition and temperature growth optimum differed. The phenotypic differences between our strains and Subtercola spp. are supported at the phylogenetic level. The type strain of Agreia bicolorata gen. nov., sp. nov. showed 
96.8-97.1\% 16S rDNA sequence similarity with members of Subtercola spp., which is approximately in the same range as similarities reported for other closely related genera of the family Microbacteriaceae, e.g. Subtercola and Clavibacter $(95 \cdot 1-97 \cdot 1 \%)$, or Clavibacter, Frigoribacterium and Rathayibacter (96·1-97·1\%) (Kämpfer et al., 2000; Männistö et al., 2000).

\section{Ecology}

There is no unambiguous evidence to show whether bacteria assigned to Agreia bicolorata gen. nov., sp. nov. are nematode-associates like Rathayibacter spp., i.e. carried by nematodes into plants and developing inside plant galls, or secondary settlers of the galls (their surface sections), descending from the microbial communities of the phyllosphere. For the first scenario, arguments may be as follows: (i) Agreia bicolorata gen. nov., sp. nov. comprised a significant proportion of the population grown from the ground gall suspension; (ii) the bacteria were not found in plants that lacked nematode galls; (iii) the bacteria formed abundant slime which is thought to be a characteristic feature of nematode-associated bacteria (Bird, 1985); and (iv) their morphology was similar to that of bacteria observed within the galls by electron microscopy (Evtushenko et al., 1994). Nevertheless, there is a probability that the particular bacterial associates of the nematodes are unculturable under conditions used for isolation of gall bacteria and that Agreia bicolorata gen. nov., sp. nov. is a representative of the secondary bacterial infection of galls. Further study should elucidate the ecological niche of these bacteria and their relationship with nematodes and other micro-organisms of the nematode-bacteria multicomponent complexes.

\section{Description of Agreia gen. nov.}

Agreia (Ag.re'i.a. N.L. gen. fem. n. Agreia of Agre, named to honour Nina S. Agre, a Russian microbiologist).

Colonies are yellow or yellow-orange in young cultures and can be red-orange or brown-orange with age; round, glistening, opaque, butyrous, sometimes fluid. Cells are Gram-positive, non-spore-forming, weakly motile, irregularly shaped rods. Primary branching is rarely observed. Usually mesophilic. Obligately aerobic. Catalase- and oxidase-positive. Cell wall peptidoglycan is of the B-type and contains DAB and ornithine as diamino acids; hydroxyglutamate may be present instead of some of the glutamate. Mycolic acids are lacking. The major menaquinone is MK-10, with minor amounts of MK-9. The principal phospholipids are phosphatidylglycerol and diphosphatidylglycerol. The major fatty acids are anteiso-15:0, anteiso-17:0 and iso-16:0. Forms a distinct lineage within the phylogenetic cluster of actinomycetes of the family Microbacteriaceae. The type species is Agreia bicolorata.

\section{Description of Agreia bicolorata gen. nov., sp. nov.}

Agreia bicolorata (bi.co.lo.ra.ta. M.L. n. bis two; M.L. adj. coloratum coloured; M.L. fem. adj. bicolorata two-coloured).

General morphological, chemotaxonomic and growth characteristics are as given above in the genus description. Colonies are yellow-orange to orange in young cultures and red-orange to brown-orange with age, semi-fluid or fluid. Abundant capsule is usually formed. Cells are irregular rods $(0.4-0.5 \times 1.2-2.5 \mu \mathrm{m})$ that are weakly motile. In older cultures, shorter irregular rods predominate as single cells; pairs or short chains with diphtheroid arrangements may be present. A marked rod-coccus growth cycle does not occur. Mesophilic. Thermal optimum for growth is 24-26 ${ }^{\circ} \mathrm{C}$; growth occurs at $37^{\circ} \mathrm{C}$. Cell wall peptidoglycan is of the B-type and contains $\mathrm{DAB}$, ornithine, alanine, glycine and glutamate plus hydroxyglutamate (1:1:2:2:2 molar ratio). Cell wall sugars are rhamnose, mannose and fucose. DNA $\mathrm{G}+\mathrm{C}$ content is about $67.0 \mathrm{~mol} \%$. A wide range of carbohydrate and organic acids are used for growth; utilization of succinate, acetate and propionate varied in the strains. Only a few amino acids are utilized as a source of nitrogen. $\mathrm{H}_{2} \mathrm{~S}$ is weakly produced. Voges-Proskauer test is positive and methyl red test is negative. No growth with $6 \% \mathrm{NaCl}$. Strains are susceptible to $10 \mu \mathrm{g} \mathrm{ml}^{-1}$ ampicillin, doxycycline, gentamicin, penicillin, rifampicin and tetracycline, but tolerate the same concentration of neomycin and streptomycin. Isolated from leaf galls on Calamagrostis neglecta, induced by the plant-parasitic nematode Heteroanguina graminophila (Moscow region, Russia). Type strain is VKM Ac- $1804^{\mathrm{T}}$ ( = UCM Ac-620 ${ }^{\mathrm{T}}$ ), deposited in the All-Russian collection of Microorganisms (VKM) and Ukrainian Collection of Microorganisms (UCM).

\section{ACKNOWLEDGEMENTS}

This work was financially supported by grant no. 00-04-49074 of the Russian Foundation of Basic Research and NSF grants INT 9315089 and DEB 9120006 to the Center for Microbial Ecology.

\section{REFERENCES}

Altenburger, P., Kämpfer, P., Akimov, V. N., Lubitz, W. \& Busse, H.-J. (1997). Polyamine distribution in actinomycetes with group B peptidoglycan and species of the genera Brevibacterium, Corynebacterium, and Tsukamurella. Int J Syst Bacteriol 47, 270-277.

Bird, A. F. (1981). The Anguina-Coryneform association. In Plant-parasitic Nematodes, vol. 3, pp. 303-323. Edited by B. M. Zuckerman \& R. A. Rhode. New York: Academic Press.

Bird, A. F. (1985). The nature of the adhesion of Corynebacterium rathayi to the cuticle of the infective larva of Anguina agrostis. Int $J$ Parasitol 15, 301-308.

Bousfield, I. J., Keddie, R. M., Dando, T. R. \& Shaw, S. (1985). Simple rapid methods of cell wall analysis as an aid in the 
identification of aerobic coryneform bacteria. In Chemical Methods in Bacterial Systematics, pp. 221-236. Edited by M. Goodfellow \& D. E. Minnikin. London: Academic Press.

Bradbury, J. F. (1986). Guide to Plant-pathogenic Bacteria. Kew: Commonwealth Agricultural Bureau International Mycological Institute.

Collins, M. D. \& Bradbury, J. F. (1991). The genera Agromyces, Aureobacterium, Clavibacter, Curtobacterium, and Microbacterium. In The Prokaryotes, pp. 1355-1368. Edited by A. Balows, H. G. Trüper, M. Dworkin, W. Harder \& K.-H. Schleifer. New York: Springer.

Collins, M. D. \& Jones, D. (1981). Distribution of isoprenoid quinone structural types in bacteria and their taxonomic implication. Microbiol Rev 45, 316-354.

Davis, M. I., Gillaspie, A. G., Jr, Vidaver, A. K. \& Harris, R. W. (1984). Clavibacter: a new genus containing some phytopathogenic coryneform bacteria, including Clavibacter xyli subsp. xyli sp. nov., subsp. nov. and Clavibacter xyli subsp. cynodontis subsp. nov., pathogens that cause ratoon stunting disease of sugarcane and Bermudagrass stunting disease. Int $J$ Syst Bacteriol 34, 107-117.

Evtushenko, L. I., Taptykova, S. D., Akimov, V. A. \& Dobritsa, S. V. (1989). A new species of actinomycete, Amycolata alni. Int J Syst Bacteriol 39, 72-77.

Evtushenko, L. I., Dorofeeva, L. V., Dobrovolskaya, T. G. \& Subbotin, S. A. (1994). Coryneform bacteria from plant galls induced by nematodes of the subfamily Anguininae. Russ $J$ Nematol 2, 99-104.

Evtushenko, L. I., Dorofeeva, L. V., Subbotin, S. A., Cole, J. R. \& Tiedje, J. M. (2000). Leifsonia poae gen. nov., sp. nov., isolated from nematode galls on Poa аппиа, and reclassification of 'Corynebacterium aquaticum' Leifson 1962 as Leifsonia aquatica (ex Leifson 1962) gen. nov., nom. rev., comb. nov. and Clavibacter xyli Davis et al. 1984 with two subspecies as Leifsonia xyli (Davis et al. 1984) gen. nov., comb. nov. Int J Syst Evol Microbiol 50, 371-380.

Gledhill, W. E. \& Casida, L. E., Jr (1969). Predominant catalasenegative soil bacteria. III. Agromyces, gen. n., microorganisms intermediary to Actinomyces and Nocardia. Appl Microbiol 18, 340-349.

Gnilozub, V. A., Streshinskaya, G. M., Evtushenko, L. I., Naumova, I. B. \& Shashkov, A. S. (1994). 1,5-Poly(ribitol phosphate) with tetrasaccharide substituents in the cell wall of Agromyces fucosus subsp. hippuratus. Biokhimiya 59, 1892-1899 (in Russian).

Groth, I., Schumann, P., Weiss, N., Martin, K. \& Rainey, F. A. (1996). Agrococcus jenensis gen. nov., sp. nov., a new genus of actinomycetes with diaminobutyric acid in the cell wall. Int $J$ Syst Bacteriol 46, 234-239.

Gummins, C. S., Lelliott, R. A. \& Rogosa, M. (1975). Genus I. Corynebacterium Lehmann and Neumann 1896, 350. In Bergey's Manual of Determinative Bacteriology, 8th edn, pp. 602-617. Edited by R. E. Buchanan \& N. E. Gibbons. Baltimore: Williams \& Wilkins.

Gupta, P. \& Swarup, G. (1972). Ear-cockle and yellow ear rot disease of wheat. II. Nematode bacterial association. Nematologica 18, 320-324.

Jago, M. V., Payne, A. L., Peterson, J. E. \& Bagust, T. J. (1983). Inhibition of glycosylation by corynetoxin, the causative agent of annual ryegrass toxicity: a comparison with tunicamycin. Chem Biol Interact 45, 223-234.
Kämpfer, P., Rainey, F. A., Andersson, M. A., Nurmiaho Lassila, E.-L., Ulrych, U., Busse, H.-J., Weiss, N., Mikkola, R. \& SalkinojaSalonen, M. (2000). Frigoribacterium faeni gen. nov., sp. nov., a novel psychrophilic genus of the family Microbacteriaceae. Int J Syst Evol Microbiol 50, 355-363.

Kimura, M. \& Ota, T. (1972). On the stochastic model for estimation of mutational distance between homologous proteins. J Mol Evol 2, 87-90.

Komagata, K. \& Suzuki, K. (1986). Genus Curtobacterium Yamada and Komagata $1972425^{\mathrm{AL}}$. In Bergey's Manual of Systematic Bacteriology, vol. 2, pp. 1313-1317. Edited by P. H. A. Sneath, N. S. Mair, M. E. Sharpe \& J. G. Holt. Baltimore: Williams \& Wilkins.

Krall, E. L. (1991). Wheat and grass nematodes: Anguina, Subanguina, and related genera. In Manual of Agricultural Nematology, pp. 721-760. Edited by W. R. Nickle. New York: Marcel Dekker.

McKay, A. C. \& Ophel, K. M. (1993). Toxigenic Clavibacter/ Anguina associations infecting grass seedheads. Annu Rev Phytopathol 31, 151-167.

Männistö, M. K., Schumann, P., Rainey, F. A., Kämpfer, P., Tsitko,I., Tiirola, M. A., Salkinoja-Salonen, M. S. (2000). Int J Syst Evol Microbiol 50, 1731-1739.

Ophel, K. M., Bird, A. F. \& Kerr, A. (1993). Association of bacteriophage particles with toxin production by Clavibacter toxicus, the causal agent of annual ryegrass toxicity. Phytopath$\operatorname{ology}$ 83, 676-681.

Park, Y. H., Suzuki, K., Yim, D. G. \& 7 other authors (1993). Suprageneric classification of peptidoglycan group B actinomycetes by nucleotide sequencing of $5 \mathrm{~S}$ ribosomal RNA. Antonie Leeuwenhoek 64, 307-313.

Price, P. G., Fisher, J. M. \& Kerr, A. (1979). On Anguina funesta n. sp., and its association with Corynebacterium sp. in infected Loluim rigidum. Nematologica 25, 76-85.

Riley, I. T. (1987). Serological relationships between strains of coryneform bacteria responsible for annual ryegrass toxicity and other plant-pathogenic corynebacteria. Int J Syst Bacteriol 35, 153-159.

Riley, I. T. \& McKay, A. C. (1990). Specificity of the adhesion of some plant pathogenic microorganisms to the cuticle of the nematodes in the genus Anguina (Nematoda: Anguinidae). Nematologica 36, 90-103.

Riley, I. T. \& Ophel, K. M. (1992). Clavibacter toxicus sp. nov., the bacterium responsible for annual ryegrass toxicity in Australia. Int J Syst Bacteriol 42, 64-68.

Riley, I. T., Reardon, T. B. \& McKay, A. C. (1988). Genetic analysis of plant pathogenic bacteria in the genus Clavibacter using allozyme electrophoresis. J Gen Microbiol 134, 3025-3030.

Saitou, N. \& Nei, M. (1987). The neighbour-joining method: a new method for reconstructing phylogenetic trees. Mol Biol Evol 4, 406-425.

Sasaki, J., Chijimatsu, M. \& Suzuki, K. (1998). Taxonomic significance of 2,4-diaminobutyric acid isomers in the cell wall peptidoglycan of actinomycetes and reclassification of Clavibacter toxicus as Rathayibacter toxicus comb. nov. Int J Syst Bacteriol 48, 403-410.

Schleifer, K. H. \& Kandler, O. (1972). Peptidoglycan types of bacterial cell walls and their taxonomic implications. Bacteriol Rev 36, 407-477.

Shashkov, A. S., Malysheva, V. A., Streshinskaya, G. M., Naumova, I. B. \& Evtushenko, L. I. (1993). Poly(ribitol furanosyl- 
phosphate) in Agromyces cerinus subsp. nitratus cell wall. Bioorg Khim 19, 433-437.

Shashkov, A. S., Streshinskaya, G. M., Gnilozub, V. A., Evtushenko, L. I. \& Naumova, I. B. (1995). Poly(arabitol phosphate) teichoic acid in the cell wall of Agromyces cerinus subsp. cerinus VKM Ac-1340. FEBS Lett 371, 163-166.

Subbotin, S. A. \& Ivanova, T. S. (1991). The structure of galls on leaves of Ferula kuhistanica induced by Heteroanguina ferulae. Bot Zh 76, 1596-1599.

Suzuki, K., Sasaki, J., Uramoto, M., Nakase, T. \& Komagata, K. (1997). Cryobacterium psychrophilum gen. nov., sp. nov., nom. rev., comb. nov., an obligately psychrophilic actinomycete to accommodate 'Curtobacterium psychrophilum' Inoue and Komagata 1976. Int J Syst Bacteriol 47, 474-478.

Takeuchi, M. \& Hatano, K. (1998). Union of the genera Microbacterium Orla-Jensen and Aureobacterium Collins et al. in a redefined genus Microbacterium. Int $J$ Syst Bacteriol 48, 739-747.

Takeuchi, M., Weiss, N., Schumann, P. \& Yokota, A. (1996). Leucobacter komagatae gen. nov., sp. nov., a new aerobic grampositive, nonsporulating rod with 2,4-diaminobutyric acid in the cell wall. Int J Syst Bacteriol 46, 967-971.

Thompson, J. D., Higgins, D. G. \& Gibson, T. J. (1994). CLUSTAL $\mathrm{W}$ : improving the sensitivity of progressive multiple sequence alignment through sequence weighting, position-specific gap penalties and weight matrix choice. Nucleic Acids Res 22, 4673-4680.

Vidaver, A. K. (1982). The plant pathogenic corynebacteria. Annu Rev Microbiol 36, 495-517.

Vogel, P., Stynes, B. A., Coackley, W., Yeoh, G. T. \& Petterson, D. S. (1982). Glycolipid toxins from parasitised annual ryegrass: a comparison with tunicamycin. Biochem Biophys Res Commun 105, 835-840.

Weisburg, W. G., Barns, S. M., Pelletier, D. A. \& Lane, D. J. (1991). $16 \mathrm{~S}$ ribosomal DNA amplification for phylogenetic study. $J$ Bacteriol 173, 697-703.

Wen, Y. C. \& Viglierchio, D. R. (1992). Bacterial associates of Anguina species isolated from galls. Fundam Appl Nematol 15, 231-234.

Zgurskaya, H. I., Evtushenko, L. I., Akimov, V. N. \& Kalakoutskii, L. V. (1993). Rathayibacter gen. nov., including the species Rathayibacter rathayi comb. nov., Rathayibacter tritici comb. nov., Rathayibacter iranicus comb. nov., and six strains from annual grasses. Int J Syst Bacteriol 43, 143-149.

Zhou, J., Davey, M. E., Figueras, J. B., Rivkina, E., Gilichinsky, D. \& Tiedje, J. M. (1997). Phylogenetic diversity of a bacterial community determined from Siberian tundra soil DNA. Microbiology 143, 3913-3919. 